\title{
Web-based virtual tour for Tarlac's Pilgrimage Churches
}

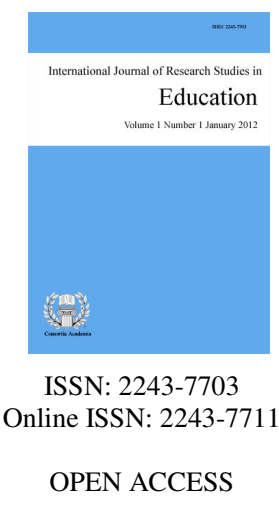

Caro, Carisma

Holy Angel University, Philippines (carismacaro@gmail.com; ccarisma@hau.edu.ph)

\section{Abstract}

This study on the development of a Web-based Virtual Tour for Tarlac's Pilgrimage Churches provides brief computer-generated visit and intends to assist in providing possible route for the users. Rapid Application Development was used as the Software Development Methodology. Four (4) IT experts were asked to evaluate the system in terms of: usability/ user interface, maintainability and security, which resulted to 3.87 grand mean. Suggestions and feedback were used to improve the developed application before the user evaluation. One hundred forty-one (141) end users were also asked to evaluate the acceptance level of the web application in terms of: functional suitability, usability/user interface, maintainability, and portability, which resulted to grand mean of 4.33. Based on the evaluation results, the web application was able to perform its intended functions and recommended to be utilized by the church devotees.

Keywords: virtual tour, web-based application, pilgrimage churches, online church activities, web application 


\section{Web-based virtual tour for Tarlac's Pilgrimage Churches}

\section{Introduction}

In early times, Church and emerging technology did not go hand in hand, since the former focused on the public religious service or worship of humans while the latter was devoted to the forging of significant advances as the result of a series of evolutionary changes or breakthroughs for human lives. "Nowadays, the Church pronounces itself in favor of modern technology, as much as it enables people to communicate directly throughout the world, in directly personal ways (e-mail, texting, Twitter, Skype, etc.) as well as in more formal or purely informational forms of group collaboration and instruction. Technology helps the Church evangelize globally by providing various means of communication through which the latter fulfills its mission of preaching the Good News to all" (McCloskey, 2014).

According to Stetzer, "technology is a resource that can be used for God's glory". It enables the Church to perform its mission by creating community and discipleship through communications using Facebook and Twitter or a Church blog. Today, this is evident with Pope Francis owning the largest Twitter account that reached over 40 million followers in 2017 (Stetzer, 2014). In addition, Good News Web Designers Association (n.d.), one emerging technology that gets the most feedback, and which was described to truly evangelize the visitor is the virtual tour. "Virtual tours are over the web in many different scenarios: touring a campus, displaying consumer products, and documenting a trip. These tours provide information using images, movies, and sound to provide users with navigation in such a way that they feel as if they are experiencing the information in real time. These tours are usually driven by mouse clicks, whether clicking on an image gallery, movie gallery or panning around a panoramic image" (Bessey, 2013).

One of the emerging uses of virtual tour for religious purposes is its function as an alternative to Visita Iglesia, a Roman Catholic Lenten tradition where devotees have at least seven (7) churches to attend and pray. Today's world, the Visita Iglesia has extended into a strictly religious tradition, as visitors often fly around the world to visit old colonial churches and cathedrals. In the Philippines, the practice gotten a 21 st-century upgrading with the launch of the Catholic Bishops' Conference of the Philippines' visitaiglesia.net and other Visita Iglesia websites, which enable users, especially overseas Filipinos and the elderly, to conduct virtual church visits from the comfort of their homes (Tan, 2016).

The Diocese of Tarlac is a pastoral district under the Christian Church that covers the whole province of Tarlac. The province comprises an area of territory of 3,053.4 square kilometers and a total population of 1,243,449 as per August 2007 Census. "Before the diocese's creation on February 16, 1963, the province belonged to two different dioceses. Its capital town of Tarlac and the southern towns belonged to the then Diocese of San Fernando, Pampanga, while the northern towns were part of the Diocese of Lingayen - Dagupan. Today, it is a suffragan of the Archdiocese of Pampanga, the melting pot of Kapampangans, Ilocanos, Pangasinenses, Tagalogs, and the Aetas as they live together in harmony and peace. The Diocese of Tarlac has 7 Vicariate, comprising a total of 59 parishes, and its jurisdiction covers a population of 887,089, 71 percent of whom are Catholics" (The Catholic Directory of the Philippines, 2016).

Recently, the absence of the list of churches and directions on how to get to a particular church in the said diocese have become devotees' concerns that usually arise during the annual Visita Iglesia. Devotees want to have a means to be guided safely to their church destinations using technological products, such as maps and navigation systems (NS).

Navrotska (2012) identified tools to create a virtual tour, which was considered in the development of the study. Virtual tours developed in the research studies of Cho et al. (2008) and Miller (2013) targeted audiences for marketing purposes and found its significance in utilizing the systems to their locale, similar to the intention

18 Consortia Academia Publishing (A partner of Network of Professional Researchers and Educators) 
of the developed system that focused on showcasing pilgrimage churches within the province to attract pilgrims and tourists. The developed system only focused on using 2D images in panoramic view, however, the intention of preservation of pilgrimage churches' historical, architectural and spiritual significance incline to be in the same way.

Navigation system is an instrument that determines the position of and the route to a particular place. "It is a Global Positioning System (GPS) based electronic system in a vehicle or mobile device that provides a real-time map of the current location of the user as well as step-by-step directions to a requested destination" (Navigation System, n.d). Modern navigation systems are intuitive, implementing various algorithms to enhance routing and rerouting suggestions for the users. Shortest path algorithms integrated to systems and applications aim to serve as better tools for routing means. This is possible through the scope that they cover, and the features incorporated. Navigation is being integrated into virtual tours to enhance user experience in terms of destination directions.

Currently, the church devotees in Tarlac rely on signboards and the local citizens for direction towards their destinations within the province. Sometimes, they inquire from nearby parishes or use other visita iglesia promoting websites like Tara Gumala: Visita Iglesia in Tarlac and Pampanga for suggestions on the churches to visit within the area. It was in view of the foregoing situation that this study implemented a web-based virtual tour with navigation system, a feature that provides a unique opportunity to promote churches in the Diocese of Tarlac to prospective devotees and tourists. The researcher tailored the system in a way that it also concentrated on catering the needs of the church parishioners and personnel of Tarlac's Pilgrimage Churches in terms of information management and dissemination.

\subsection{Objective of the study}

The general objective was to develop a Web-based Virtual Tour for Tarlac's Pilgrimage Churches that provides a brief computer-generated visit and intends to assist in providing possible routes for the users. Specifically, the study aims to achieve the following objectives:

$>\quad$ To aid in providing Tarlac's Pilgrimage Churches vital information to the devotees and potential audience particularly on their architectural, historical, and spiritual significance.

$>\quad$ Provide churches information on their mass and confession schedule.

$>$ Determine the shortest route and average time for getting to a specific church in the application's navigation system.

\section{Methodology}

\subsection{Research design}

In this study, the researcher used the Developmental Research approach for the Web-based Virtual Tour for Tarlac's Pilgrimage Churches in which it was specified, designed, created, tested, and then evaluated for its significance. The approach was chosen due to the intention of the researcher of making an innovative means using the available technologies that may improve the current way of doing church pilgrimage.

\subsection{Research participants}

Using the purposive sampling, the respondents are IT Experts, church personnel and devotees on behalf of Diocese of Tarlac who will manage the application. Target respondents were 200 which amounted to the church personnel, devotees, and IT experts. Only four (4) IT experts, one hundred forty-one (141) end-users, which consist of five (5) Church personnel and 136 randomly selected devotees, validated the website. Questionnaires were distributed to the respondents to elicit necessary information for the evaluation of the system. 


\subsection{Research instrument}

The evaluation instrument used was based on ISO/IEC 25010 (Figure 1), an international standard for system and software quality models. "The quality model is the cornerstone of a product quality evaluation system, which determines the degree to which the system satisfies the stated and implied needs of its various stakeholders, and thus provides value. Those stakeholders' needs, which include functionality, performance, security, maintainability, and others, are precisely what represent in the quality model” (ISO/IEC 25010, 2017). The system was evaluated according to the international standard for Human Computer Interaction, which includes functional suitability, usability/user interface, maintainability, portability, and security. For IT Experts, websites' functionality, usability, and user interface requirements were the criteria used to evaluate the system. The church personnel and devotees evaluated the websites' portability/accessibility, maintainability, functionality suitability, usability, and user interface.

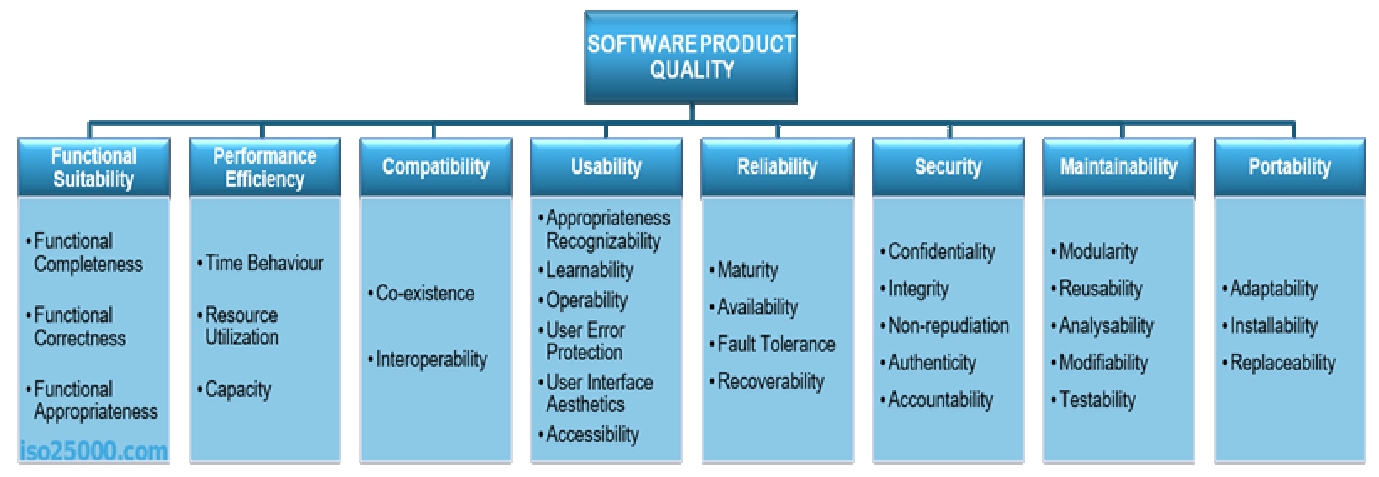

Figure 1. ISO 25010 Model

\subsection{Sources of data}

The researchers used the quantitative type of research to gather information about the proposed. Web-based virtual tour. The researcher interviewed the Chair of Diocesan Commission for the Cultural Heritage of the Church, and other parish church personnel to identify and study the existing scenarios. The interview also allowed the researcher to gather necessary information and other arrangements needed during data gathering. The researcher used both the library and the Internet sources to gather literature and studies related to the current research to establish the application's necessity.

\subsection{Research procedure}

The following procedure was followed by the researchers throughout the development and completion of the whole study. In the specification of requirements phase, the identification and studying of the existing scenarios. The interview allowed the researcher to gather necessary information and other arrangements needed during data gathering. The researcher interviewed the Chair of Diocesan Commission for the Cultural Heritage of the Church, and other parish church personnel to identify and study the existing scenarios. Also included in this phase, the minimum hardware and software requirements used in system development of the web-based system are identified. Database and storage requirements are Amazon S3 and Dropbox. The programming language, framework, and tool that the researcher used in the development of the system are the Apache Maven, Java, Javascript, Laravel, and Mapbox API.

The website development phase encompasses two processes, which are designing, and developing/coding generation. Design process describes in depth the desired functions and procedures, including screen layouts, validating the mockups, reviewing the content, creating and updating text reception and other documentation. For the development/coding process, the design layouts and system models were converted to codes. Using the identified technological software tools, such as Java 8, Apache Maven, Laravel, JavaScript, Mapbox API, which 
were used for the front-end and back-end; Amazon Web Services (AWS), which was used in hosting; and Amazon S3 and Dropbox, which served as storage for the data, the website was developed. The coding started in building the database and CMS of the website, the customization of the application was taken in consideration together with the functionalities. Login account for the church personnel in-charge was also built for the security of the system data. The virtual tour used 2D images, camera captured images, in creating the 180-degree panoramic view, architectural, historical and spiritual significance of the pilgrimage churches.

For the testing phase, the researcher uploaded the website using AWS as a domain provider. The system content, design and transactions were tried, and errors were corrected based on user requirements and system design. Developed system prototypes were also demonstrated to the church personnel to gain feedback and used to further enhance the system.

\subsection{Statistical treatment of data}

To determine the developed system's degree of acceptance, the following scale, also known as Likert's Scale, was used as a rating scale for IT experts and end-users' evaluations. While the statistical treatment used for the post-test data was Weighted Mean formula, and "Likert Scale (5 - Excellent, 4 - Very Satisfactory, 3 Satisfactory, 2 - Good and 1 - Poor)" (Nemoto \& Beglar, 2014) for the verbal interpretation of the mean rating. The tools used to present an organized means of data analysis and interpretation: (1) tables; (2) frequency distribution; and (3) Weighted Arithmetic Mean (WAM).

\section{Results}

Table 1 shows the evaluation results from IT experts, the highest-rated criterion belonged to security having mean of 4.25, due to the presence of Administrator account for authorized access and data protection, while maintainability rated the lowest mean of 3.50, due to the presence of one (1) Admin account only, and its readiness to adapt and manage failure or change.

\section{Table 1}

Evaluation of the web application by IT experts

\begin{tabular}{|c|c|c|}
\hline Criteria & Mean & $\begin{array}{c}\text { Verbal } \\
\text { Interpretation }\end{array}$ \\
\hline $\begin{array}{l}\text { Maintainability (Modifiability, Testability, Modularity, Reusability, Analysability) } \\
\text { The web application uses different levels of access to its users. } \\
\text { The web application shares the same data to all users. } \\
\text { It is easy to find a failure when it occurs. } \\
\text { The web application's changes are easy to test. }\end{array}$ & 3.50 & $\begin{array}{c}\text { Very } \\
\text { Satisfactory }\end{array}$ \\
\hline $\begin{array}{l}\text { Security (Confidentiality, Integrity, Non-Repudiation, Authenticity) } \\
\text { The web application has the user's login credentials. } \\
\text { The web application has unauthorized access protection. } \\
\text { The web application prevents users' changes to processed information. } \\
\text { The web application uses a unique username and password. }\end{array}$ & 4.25 & $\begin{array}{c}\text { Very } \\
\text { Satisfactory }\end{array}$ \\
\hline $\begin{array}{l}\text { Usability and User Interface (Appropriateness recognizability, Learnability, User interface } \\
\text { aesthetics, Accessibility Operability, User error protection) } \\
\text { The web application has tools for users' guides and tips. } \\
\text { The web application facilitates the users' data entry. } \\
\text { The web application attributes are easy to operate. } \\
\text { The web application alerts the users when an error occurs. } \\
\text { The web application's design elements are appropriate. } \\
\text { The web application's graphical elements are easy to understand. } \\
\text { The web application's navigation is easy to understand. } \\
\text { The web application is accessible on different platforms using the Internet. }\end{array}$ & 3.88 & $\begin{array}{c}\text { Very } \\
\text { Satisfactory }\end{array}$ \\
\hline Weighted Mean & 3.87 & $\begin{array}{c}\text { Very } \\
\text { Satisfactory }\end{array}$ \\
\hline
\end{tabular}

Table 2 shows the end-users' evaluation, usability and user interface, and maintainability criteria acquired the highest mean of 4.34 , due to its accessibility and easiness to navigate, and improved readiness to adapt and 
Caro, C.

manage failure or change, while portability/accessibility criterion obtained the lowest mean of 4.32, due to website content loading issue during testing. All the focused criteria have the verbal interpretation of very satisfactory.

Table 2

Evaluation of the web application by church personnel and user

\begin{tabular}{|c|c|c|}
\hline Criteria & Mean & $\begin{array}{c}\text { Verbal } \\
\text { Interpretation }\end{array}$ \\
\hline $\begin{array}{l}\text { Portability / Accessibility (Adaptability, Installability) } \\
\text { The web application's interface adapts to different screen sizes. } \\
\text { The web application runs in different browsers properly. }\end{array}$ & 4.32 & $\begin{array}{c}\text { Very } \\
\text { Satisfactory }\end{array}$ \\
\hline $\begin{array}{l}\text { Maintainability (Modifiability, Testability, Modularity, Reusability, Analysability) } \\
\text { It is easy to find a failure when it occurs. } \\
\text { The web application's changes are easy to test. } \\
\text { The web application uses different levels of access to its users. } \\
\text { The web application shares the same data to all users. } \\
\text { The web application is easy to modify and adapt. }\end{array}$ & 4.40 & $\begin{array}{c}\text { Very } \\
\text { Satisfactory }\end{array}$ \\
\hline $\begin{array}{l}\text { Functionality Suitability (Functional Appropriateness Functional Completeness, Functional } \\
\text { Correctness) } \\
\text { The web application's interface adapts to different screen sizes. } \\
\text { The web application runs in different browsers properly. } \\
\text { The web application has all the functions required. } \\
\text { The web application does what is appropriate and correct. } \\
\text { The web application is precise in executing its functions. } \\
\text { The web application facilitates the user' experience. }\end{array}$ & 4.33 & $\begin{array}{c}\text { Very } \\
\text { Satisfactory }\end{array}$ \\
\hline $\begin{array}{l}\text { Usability and User Interface (Appropriateness recognizability, Learnability, Operability, User } \\
\text { error protection, User interface aesthetics, Accessibility) } \\
\text { The web application has tools for users' guides and tips. } \\
\text { The web application facilitates the users' data entry. } \\
\text { The web application attributes are easy to operate. } \\
\text { The web application alerts the users when an error occurs. } \\
\text { The web application's design elements are appropriate. } \\
\text { The web application's graphical elements are easy to understand. } \\
\text { The web application's navigation is easy to understand. } \\
\text { The web application is accessible on different platforms using the Internet. }\end{array}$ & 4.34 & $\begin{array}{c}\text { Very } \\
\text { Satisfactory }\end{array}$ \\
\hline Weighted Mean & 4.34 & $\begin{array}{c}\text { Very } \\
\text { Satisfactory } \\
\end{array}$ \\
\hline
\end{tabular}

\section{Discussion and conclusion}

This research study has been conducted for the church devotees of the Diocese of Tarlac by providing a brief computer-generated visit and intends to assist in suggesting possible routes for the users. All information in this study was gathered through interviews, observations, research, consultations, with the Chair of Diocesan Commission for the Cultural Heritage of the Church, researcher's technical adviser, and selected IT experts, and evaluation from IT experts, and randomly selected church personnel and devotees.

The evaluation instruments were based on the ISO 25010 quality standard focused on functional suitability, security, usability and user interface, maintainability, and portability / accessibility criteria. Respondents of the distributed evaluation tools were 4 IT experts, and 141 end-users, consisting of 5 church personnel, and 136 devotees. The evaluation results from IT experts were used to improve the developed system, and then the developed system was evaluated by the user and gauged its acceptance level. Based on the evaluation results from IT experts, the highest rated criterion belonged to security having mean of 4.25 , due to the presence of Administrator account for authorized access and data protection, while maintainability rated the lowest mean of 3.50, due to the presence of one (1) Admin account only, and its readiness to adapt and manage failure or change. For the end-users' evaluation, usability and user interface, and maintainability criteria acquired the highest mean of 4.40 , due to its accessibility and easiness to navigate, and improved readiness to adapt and manage failure or change, while portability / accessibility criterion obtained the lowest mean of 4.32 , due to website content loading issue during testing. All the focused criteria have the verbal interpretation of very satisfactory.

22 Consortia Academia Publishing (A partner of Network of Professional Researchers and Educators) 
The following conclusions were drawn from the study's findings:

$>\quad$ The Web-based Virtual Tour for Tarlac's Pilgrimage Churches met all the objectives set in the research study. The developed system's Admin account provided security for authorized access and data protection for the published contents on the website.

$>\quad$ The developed system utilized 2D images, for 180-degree panoramic view and significance, and texts, for descriptive illustration of the pilgrimage church information, as web contents in presenting the virtual tour feature of pilgrimage churches within Tarlac province. It also included a navigation system that can suggest to the user possible shortest route from one church or user's current location to the next church destination.

$>\quad$ The study's intention for the development of a web-based system to be an informative tool for the pilgrimage churches of the Diocese of Tarlac was evident as reflected in the results of the evaluation from IT experts and end-users.

\section{References}

All Answers Ltd. (November 2017). Web based information systems. Retrieved from https://www.ukessays.com/essays/information-systems/web-based-information-systems.php?vref=1

Beal, V. (n.d.). Virtual tour definition. Webopedia. Retrieved from https://www.webopedia.com/TERM/V/virtual_tour.html

Bessey, S. (2013). Virtual 3D environments: Implementations of 3D environments for virtual tours and online communication. Retrieved from http://scholarworks.rit.edu/theses/6299/

Cho, Y.-H., Wang, Y., \& Fesenmaier, D. R. (2008). The web-based virtual tour in tourism marketing. Searching for experiences. Journal of Travel \& Tourism Marketing, 12(4), 1-17. https://doi.org/10.1300/J073v12n04_01

Directions. (n.d.). In mapbox. Retrieved from https://www.mapbox.com/help/how-directions-work/

Good News Web Designers Association. (n.d.). How to evangelize with your website. Retrieved from http://gnwda.org/tutorials/evangelize/index.html

ISO/IEC 25010. (2017). Retrieved from http://iso25000.com/index.php/en/iso-25000-standards/iso-25010

McCloskey, J. (2014). The perils of technology, CatholiCity. Retrieved from http://www.catholicity.com/mccloskey/perils-of-tech.html

Miller, S. (2013). A virtual tour of the engineering school and technical report on VRML 2.0. University of Virginia.

Navigation System. (nd). Browse encyclopedia. Retrieved from https://www.pcmag.com/encyclopedia/term/gps Navrotska, U. (2012). Virtual museum: Recreate the reality. Polo Territoriale di Como.

Nemoto, T., \& Beglar, D. (2014). Developing Likert-scale questionnaires. In N. Sonda \& A. Krause (Eds.), JALT2013 Conference Proceedings. Tokyo: JALT.

Panorama. (n.d.). In Dictionary.com. Retrieved from http://www.dictionary.com/browse/panorama

Stetzer, E. (2014). 3 ways technology enables the mission of the church. Retrieved from http://www.christianitytoday.com/edstetzer/2014/october/3-ways-technology-enables-mission-of-church .html

Tan, N. (2016). Origins of the Visita Iglesia. Retrieved from https://www.rappler.com/newsbreak/iq/55546-origins-visita-iglesia

The Catholic Directory of the Philippines. (2016). Catholic Bishop Conference of the Philippines and Claretian Publications. 
Caro, C.

24 Consortia Academia Publishing (A partner of Network of Professional Researchers and Educators) 